\title{
284. 喉頭全摘術後の嚥下機能
}

\section{—正常例との比較—}

\section{部坟弘彦・本多芳男（茲大）}

頭頸部悪性腫湯により渎頭摘出した場合，一般に切 除摘出範囲，再建材料によってもかわるが，術後の1 回嘫下量, 嚓下時間に変化をきたしてくる。今回我々 㹥, 咽頭全摘術後 (单純喉頭全摘術, 咽頭㘈頭頸部食 道摘出術 (咽喉食摘)）症例に対して，X 線側面透視下 で欌下時内压測定の同時測定を行い, 正常例と比較検 討し，若干の知見を得たので報告した。

対象は, 正常群として成人男子 6 例で, 平均年龄50.3 葴, 喉頭摘出群 (喉摘群) として, 単純喉頭全摘出 (単 純喉摘） 4 例，咽喉食摘 2 例（再建材料として，1 例 は逰離空腸，1例は遊離前腕皮弁）計12例を対象とし た. 测定装置, 方法：圧力トランスデューサーは Gaeltec 社製 Type 16CT を使用. これはシリコンコー ティングした外径 7Frで 3つのセンサーを同一方向 性とし，各センサーを $30 \mathrm{~mm}$ 間隔に設置した。記録計 として日本電気三栄製オムニコーダ $8 \mathrm{M} 14$ で $50 \mathrm{~mm} /$ secで記録。 X 線側面透視像で得られた画面をビデオ レコーダーに録画し，記録計上に得られた嚥下圧波形 を時間的に一致させるためLPL 社製ビデオテロッパ 一を使用することによりVTR 上に同時記録した。得 られたデータを記録計とともにVTR 画面上で1/
松井真人・太田正治（太田総合）

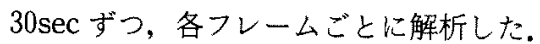

結果 1) 静止圧：正常群は,第 6 頻椎上端を中心に 平均 $39 \mathrm{~mm}, 38.5 \mathrm{mmHg}$ の静止圧陽圧帯部を認めた。 しかし，喉頭全摘群はこの陽圧帯部が低下し，単純喉 摘群では, 第 6 頸椎上端で $7.5 \mathrm{mmHg}$ 程度の陽圧を示 した。 さらに咽喉食摘群の静止圧は測定不能で陽圧帯 は消失していた。これは，陽圧带部をしめる輪状咽頭 筋, 下咽頭収縮筋の切断，および皮弁再建によるもの

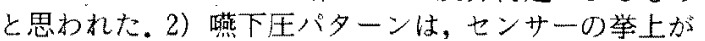
良好なタイプと不良なタイプがあり, 正常型, 疗攣型, 無反応型に分類できた。 それぞれのタイプについて検 討を加える。質問 大森孝一(京大).1）輪状咽頭 筋を縫合しない方が食道発声良好という意見もある が，どう考えるか．2）スライドで呈示された EMGは どこから採取したか。＼cjkstart応答 1) CP の縫合は単純 啹摘群で全例同程度に約 $2 / 3$ 縫合した。 2) 喉摘群の舌 骨下筋群に刺入したが，筋肉の同呈は困難であった。 質問 稲木匠子(松山赤十字)。七ンサ一挙上度に差が 生じた原因は，術後の嶼下圧測定でも異なっていたか どうか。応答 舌の後方運動が少ない症例ではセ ンサーの挙上が低かった。

\section{5. 当科における最近15年間の異物統計と摘出術の工夫}

中田智愛子・石渡 隆 - 田中裕美子 - 大竹 守 - 牧上久仁子

多湖恵里子・宮野良隆・荒牧 元（東女医大第 2)

はじめに 昭和50年 1 月より，平成元年12月までの 15年間に当科において摘出を行った異物症例につき, 統計的観察を行ったので報告し，あわせて摘出につい ての工夫を述べた。

異物症例の統計 緿症例数は393例であり, 咽頭暴物 139例 (35.4\%)，外耳道異物93例 $(23.7 \%)$ ，鼻腔異物 84 例 $(21.3 \%)$ ，食道異物 44 例 $(11.2 \%)$ ，気管支異物 24例 $(6.1 \%)$ ，㬋頭異物 9 例 $(2.3 \%)$ であった。気管 支異物は隇少傾向にあった。年歯, 性別では鼻空異物, 気管支異物，食道異物が 5 歲以下の乳幼巟に多く(各々 7 例 (84.5\%)，22例 (83.3\%)，28例 $(63.6 \%)) ，$ 咽 頭異物は20歳以上に多加った（114例 $(85.07 \%))$ 。外 耳道異物では20歳までが70\%を占めた。性別では外耳 道異物で2:1と男性に多く，食道異物でやや女性に多 いほかは性差を認めなかった。異物の種類は，外耳道 異物として玩具24例 $(25.8 \%)$ ，昆虫14例 $(15.1 \%)$ が 主だったものであり，鼻腔でも玩具57例 (67.8\%) が 多く，特に球状のものが多かつた，咽頭は 1 例の義霜
異物を除さすべて魚骨であった，気管支異物は24例中 18例 $(75 \%)$ が豆類であったが，他に玩具，PTP，六 ジクギ等があった，食道異物は貨幣が23例 $(52.3 \%)$ と過半数を占めたが，これは2例の学童を除き，すべ て5歳以下の乳幼児であった。虫大他に義歯や，近年 問題になっているPTPが50歳以上の高齢者にみられ た.

治療法 外耳道異物，亶腔異物の球状のものには吸 着器索考案し用いている、これにより, 周囲を障害す ることなく摘出が可能である。気管支, 食道異物では， 最近我々が共同て開発した超微細徍ファイバースコ一 プを用いて異物摘出術を試みている. $0.9 \mathrm{~mm}$ の超微細 径ファイバースコープをJackson 型硬性鏡の副管に 入れ, VTR でモニターをしながら摘出を行うが, VTR モニター下であることにより，介在部位が㹡大され， また摘出操作も複数の観察者により観察し得るという ことで教育上にも有効であると思われた。なお，各部 位における合併症, 偶発症は特に認められなかった。 